\title{
PENERAPAN TERAPI MUSIK KLASIK DALAM MENURUNKAN NYERI PADA PASIEN CA MAMMAE LITERAURE REVIEW
}

\author{
Rizqi Apriani Pujianto* ${ }^{1}$, Ricky Zainuddin ${ }^{2}$ \\ Akademi Keperawatan Makasar Jurusan Keperawatan Makassar
}

\begin{abstract}
Abstrak
Background: Music therapy is a form of therapy in the health sector using music and music activities to address various issues. Empirical evidence supports the therapeutic use of classical music in a variety of conditions including psychiatric disorders, medical problems, physical disabilities, sensory disturbance, developmental disabilities, aging problems, increase the concentration of learning, support physical exercise, reducing stress and anxiety, as well as additional treatment in cancer patients and management pain. This article analyzes the application of music therapy to reduce pain scale and by reviewing the results of this study. Methods: This study explores quantitative evidence published in electronic databases such as Pubmed, Google Scholar. Results: Research shows that a significant increase occurred in the post-intervention in reducing the pain scale for participants who received the Classical Music Therapy as compared to all the controls. Conclusion: The results showed that the classical music therapy is very useful additional treatment to reduce the scale of pain in cancer patients who have never undergone chemotherapy and nurses must be trained to perform classical music therapy.
\end{abstract}

Keywords: Music Therapy, Pain, Breast Cancer

\section{PENDAHULUAN}

Carcinoma mammae (kanker payudara) merupakan salah satu masalah kesehatan yang mengalami peningkatan secara cepat dan menjadi penyebab kedua kematian di dunia. Hal ini dapat dilihat dari semakin banyaknya laporan bahwa penyakit kanker cenderung menjadi salah satu penyebab utama kematian pada wanita (Ricky, Rachmawaty, \& Syam, 2018). Carcinoma mammae merupakan penyakit yang paling ganas akibat tumbuhnya sel kanker abnormal yang berasal dari sel-sel normal pada payudara yang dapat berasal dari kelenjar susu, saluran susu, atau jaringan penunjang seperti lemak dan saraf (Khasanah, 2013).

Menurut data World Health Organization (WHO) pada tahun 2010, memperkirakan sebanyak 206.966 wanita di Amerika Serikat terdiagnosis $\mathrm{Ca}$ mammae dan sebanyak 40.996 wanita meninggal dunia akibat $\mathrm{Ca}$ mammae. Selain itu pada tahun 2013 menurut American Cancer Society (ACS) dan National Cancer Institute (NCI) terdapat kasus baru sekitar 232.340 kasus $\mathrm{Ca}$ mammae invasif dan 39.620 kematian akibat Ca mammae (Agustina, 2015).

Di Indonesia Tahun 2010, menurut data Histopatologik; Badan Registrasi Kanker Perhimpunan Dokter Spesialis Patologi Indonesia (IAPI) dan Yayasan Kanker Indonesia (YKI). Diperkirakan angka kejadiannya di Indonesia adalah 12 dari 100.000 wanita. Penyakit ini juga dapat diderita pada laki-laki dengan 
frekuensi sekitar 1\%. di Indonesia, lebih dari $80 \%$ kasus ditemukan berada pada stadium yang lanjut, dimana upaya pengobatan sulit dilakukan (Kemenkes RI, 2015). Sulawesi Selatan sebanyak 2.975 kasus (Ricky et al., 2018).

Pada penderita $\mathrm{Ca}$ mammae akan timbul rasa nyeri apabila sel kanker sudah membesar, sudah timbul luka serta telah bermetastase ke tulang. Nyeri pada kanker payudara merupakan gabungan antara fisik dan non fisik (Sitinjak, Rulino, \& Masliah, 2018). Apabila nyeri kanker tidak ditangani segera maka akan berdampak pada fisik, psikologis, sosial, dan spiritual. Dampak fisik yang ditimbulkan antara lain seperti kelelahan, nafsu makan menurun, muntah, penurunan kekuatan otot (Munawaroh, 2018).

Terapi yang dapat menurunkan intensitas nyeri yaitu dengan Terapi farmakologis dan non farmakologis. Untuk menurunkan nyeri secara farmakologi meliputi analgesik dengan penggunaan opioid. Obat opioid ini berfungsi untuk penghilang rasa sakit yang bekerja dengan reseptor opioid di dalam sel tubuh, obat ini dibuat dari tanaman opium seperti morfin, dengan efek samping memperlambat pernapasan dan detak jantung (Rahayuwati, Ibrahim, \& Komariah, 2018).

Sedangkan Terapi non farmakologi salah satunya ialah terapi musik. Terapi musik merupakan suatu bentuk terapi dibidang kesehatan yang menggunakan musik dan aktivitas musik untuk mengatasi masalah dalam berbagai aspek fisik, psikologis, kognitif dan kebutuhan sosial individu yang mengalami cacat fisik (Faridah, 2016). Selain itu efek yang ditimbulkan seperti menurunkan nyeri dan membuat relaksasi. Rangsangan musik meningkatkan pelepasan endorfin sehingga mengurangi kebutuhan obat analgesik (Rilla, Ropii, \& Sriati, 2017).

\section{METODE PENELITIAN}

Tinjauan literatur yang dilakukan melalui penelusuran hasil-hasil publikasi ilmiah pada rentang tahun 2006-2018 menggunakan database Pubmed, google cendekia. Pada database pubmed dengan memasukkan keyword 1 "Therapy Music" ditemukan 3.000 artikel. Keyword 2 "Pain" ditemukan 1.500 artikel. Keyword 3 "Breast Cnancer" ditemukan 500 artikel. Keyword 4 dilakukan penggabungan keyword 1, 2, dan 3 yaitu "Therapy Music AND pain AND breast cancer" ditemukan 100 artikel. Setelah dilakukan pencarian artikel, selanjutnya dilakukan pembatasan jumlah artikel sesuai kriteria penelitian dengan langkahlangkah : LIMIT Abstrak ditemukan 19 artikel. LIMIT Full Text ditemukan 15 artikel. LIMIT to date (2006-2018) ditemukan 10 artikel. LIMIT of humans ditemukan 5 artikel. Limit Clinical Trial ditemukan 1 artikel.

Pada database google cendekia dengan memasukkan keyword 1 "Therapy Music" ditemukan 1.000 artikel. Keyword 2 "Therapy Music AND pain" ditemukan 500 artikel. Keyword 3 "Therapy Music AND Breast cancer" ditemukan 300 artikel. Keyword 4 'Therapy Music AND randomized controlled trial" ditemukan 200 artikel. Keyword 5 dilakukan penggabungan keyword 1, 2, 3, dan 4 yaitu 'Therapy Music" AND "Therapy Music AND pain" AND "Therapy Music AND Breast cancer" AND "Therapy Music AND randomized controlled trial" diemukan 50 artikel. Setelah dilakukan pencarian artikel, selanjutnya dilakukan pembatasan 
jumlah artikel LIMIT to date (after 2017) 20 artikel. LIMIT relevansi ditemukan 2 artikel.

\section{HASIL PENELITIAN \\ Carcinoma Mammae}

Carcinoma mammae merupakan penyakit yang paling ganas akibat tumbuhnya sel kanker abnormal yang berasal dari sel-sel normal pada payudara yang dapat berasal dari kelenjar susu, saluran susu, atau jaringan penunjang seperti lemak dan saraf (Khasanah, 2013).

Tanda yang mungkin muncul pada penderita $\mathrm{Ca}$ mammae ialah timbulnya benjolan yang tidak terasa nyeri. Benjolan itu awalnya kecil namun semakin lama maka akan semakin membesar serta menimbulkan nyeri. Benjolan tersebut melekat pada kulit atau menimbulkan perubahan pada kulit payudara, serta pada puting susu. Nyeri dapat berkurang dengan melakukan terapi non farmakologi dan farmakologi (Hidayat, Utami, Tri, \& Agrina, 2008).

Namun jangan khawatir jika ditemukan benjolan pada payudara, karena tidak semuanya berarti carcinoma (kanker) tetapi kebanyakan yang bersifat jinak (tumor) (Houghty, Veronika, \& Florensa, 2018).

\section{Nyeri}

Nyeri atau rasa sakit merupakan respon yang paling dipahami oleh individu ketika mengalami cidera. Nyeri terbagi menjadi 2 (dua) yaitu nyeri akut dan nyeri kronik. Nyeri akut merupakan nyeri yang timbul secara mendadak dan cepat menghilang, serta tidak melebihi 6 (enam) bulan. Sedangkan nyeri kronis merupakan nyeri yang timbul secara perlahan-lahan dan melebihi 6 (enam) bulan (Martini, Watiningsih, Pertama, \& Lisnayani, 2018).

Nyeri dapat muncul akibat adanya rangsangan yang diterima oleh nociceptors pada kulit, bisa intesitas tinggi maupun rendah seperti perenggangan dan suhu serta oleh lesi jaringan. Sel yang mengalami nekrotik akan merilis $\mathrm{K}+$ dan protein intraseluler. Peningkatan kadar $\mathrm{K}+$ ekstraseluler akan menyebabkan depolarisasi nociceptor, sedangkan protein pada beberapa keadaan akan menginfiltrasi mikroorganisme sehingga menyebabkan peradangan atau inflamasi. Akibatnya, mediator nyeri dilepaskan seperti leukotrien, prostaglandin E2, dan histamin yang akan merangsang nosiseptor sehingga rangsangan berbahaya dan tidak berbahaya dapat menyebabkan nyeri (hiperalgesia atau allodynia) (Baharudin, 2017).

Adapun terapi yang dapat menurunkan intensitas nyeri yaitu dengan Terapi farmakologis dan non farmakologis. Untuk menurunkan nyeri secara farmakologi meliputi analgesik dengan penggunaan opioid. Obat opioid ini berfungsi untuk penghilang rasa sakit yang bekerja dengan reseptor opioid di dalam sel tubuh, obat ini dibuat dari tanaman opium seperti morfin. Dengan efek samping seperti memperlambat pernapasan dan detak jantung (Rahayuwati et al., 2018). Sedangkan untuk terapi non farmakologi ialah terapi musik (Faridah, 2016).

\section{Terapi Musik}

Terapi musik adalah suatu bentuk terapi dibidang kesehatan yang menggunakan musik dan aktivitas musik untuk mengatasi masalah dalam berbagai aspek fisik, psikologis, kognitif dan 
kebutuhan sosial individu yang mengalami cacat fisik (Faridah, 2016).

Terapi musik ini juga mempunyai tujuan untuk membantu mengekspresikan perasaan, membantu rehabilitasi fisik, memberi pengaruh positif terhadap kondisi suasana hati dan emosi serta mengurangi tingkat kecemasan serta menurunkan intensitas nyeri pada pasien. Terapi musik juga dapat digunakan untuk berbagai kondisi termasuk gangguan kejiwaan, masalah medis, cacat fisik, gangguan sensorik, cacat perkembangan, masalah penuaan, meningkatkan konsentrasi belajar, mendukung latihan fisik, serta mengurangi stres dan kecemasan (Larasati, 2016).

Adapun efek yang ditimbulkan ialah dapat menurunkan nyeri dan membuat relaksasi. Rangsangan musik meningkatkan pelepasan endorfin sehingga mengurangi kebutuhan obat analgesik. Musik dapat memperlambat serta menyeimbangkan gelombang otak, bahkan dapat mempengaruhi irama pernapasan, denyut jantung, dan tekanan darah (Rilla et al., 2017).

\section{PEMBAHASAN}

Hasil penelitian yang dilakukan oleh (Agustini, 2018) dengan judul Pengaruh Terapi Musik Klasik Terhadap Penurunan Intensitas Nyeri Pada Pasien Post Operasi Hernia. Penelitian ini menunjukkan bahwa intensitas nyeri pada pasien post operasi hernia sebelum dilakukan pemberian terapi musik klasik diperoleh rata-rata sebesar 4,75 (nyeri sedang) pada pre test sesi 1 dan sebesar 4,05 (nyeri sedang) pada pre test sesi 2. Intensitas nyeri pada pasien post operasi hernia setelah pemberian terapi musik klasik diperoleh rata-rata sebesar 3,10 (nyeri ringan) pada post test sesi 1 dan sebesar 2,10 (nyeri ringan) pada post test sesi 2, dan dengan hasil akhir mendapatkan nilai ( $\rho$ value 0,000$)$ yang berarti terdapat pengaruh terapi musik klasik terhadap penurunan intensitas nyeri pada pasien post operasi hernia di ruang dadali RSUD Cideres Tahun 2018.

Penelitian lain yang dilakukan oleh (Boyde, Linden, Boehm, \& Ostermann, 2012) dengan judul The use of music therapy during the treatment of Cancer patients: A Collection of evidence terdapat 12 studi klinis yang dilakukan antara tahun 2001 dan 2011 terdiri dari total 922 pasien. Delapan studi secara acak uji coba terkontrol RCT (Randomized Controlled Trial), dan empat studi observasional. Empat penelitian dilakukan di bidang onkologi pediatrik, yang menunjukkan bahwa terdapat perbedaan pada perbaikan jangka pendek dalam suasana hati, relaksasi pasien, kelelahan, serta kecemasan dalam menghadapi nyeri kanker.

Penelitian lain yang dilakukan oleh (Martini et al., 2018) dengan judul Terapi Distraksi (Musik Klasik) Terhadap Penurunan Nyeri Pada Pasien Post Operasi Fraktur Di Ruang Bedah RSUD Kabupaten Buleleng. Dengan ini menunjukkan bahwa sebelum diberikan terapi distraksi (musik klasik) pada pasien post operasi fraktur di ruang Kamboja RSUD Kabupaten Buleleng, menunjukkan bahwa dari 22 pasien sebelum diberikan rata-rata mengalami intensitas nyeri 4.41 (nyeri sedang) dan setelah diberikan terapi distraksi (musik klasik), menunjukkan rata-rata intensitas nyeri pasien post operasi fraktur mengalami penurunan intensitas nyeri 2.77 (nyeri ringan), dengan nilai $p$ value $0,000(0,000<0,05)$ yang berarti terdapat pengaruh terapi distraksi (Musik Klasik) 
terhadap penurunan nyeri pada pasien post operasi fraktur di ruang kamboja RSUD Kabupaten Buleleng.

\section{KESIMPULAN DAN SARAN}

Berdasarkan hasil penelitian yang telah dilakukan dapat dilihat bahwa terapi musik klasik terbukti efektif dalam menurunkan nyeri pada pasien yang mengalami nyeri. Hal ini dapat dilihat dari kondisi klien, dimana setelah diberikan terapi musik klasik klien tampak lebih tenang dan rileks.

Diharapkan bagi perawat serta rumah sakit dapat menjadikan musik klasik sebagai terapi komplementer, serta menambah referensi untuk lebih meningkatkan mutu pelayanan yang diberikan pada pasien yang mengalami $\mathrm{Ca}$ Mammae (kanker payudara) dengan nyeri dalam pemberian terapi musik klasik.

\section{DAFTAR RUJUKAN}

Agustina,R.2015. Peran derajat differensiasi histopatologik dan stadium klinis pada rekurensi kanker. Majority, 4, no 7(juni), 129134.Retrieved from http://juke.kedokteran.unila.ac.id/in dex.php/majority/article/view/1461

Agustini, A.2018. Pengaruh terapi musik klasik terhadap penurunan intensitas nyeri, 7, no 14 (Oktober), 1-16.

Baharudin, M.2017. Patofisiologi nyeri. Simposium Nyeri, 13(1), 11-29. Retrieved from http://ejournal.umm.ac.id/index.php/ sainmed/article/view/5449

Boyde, C., Linden, U., Boehm, K., \& Ostermann, T.2012. penggunaan terapi musik selama pengobatan pasien kanker: Koleksi bukti, l(November), 24-29.

Faridah, V. N.2016. Terapi musik instrumental dan musik klasik mampu menurunkan intensitas nyeri, 09, no 02(Agustus), 1-5. Retrieved from

https://jurnal.stikesmuhla.ac.id/wpcontent/uploads/2018/01/15Virgianti-Nur-Faridah.pdf

Kemenkes RI.2015. Panduan penatalaksanaan kanker payudara. Kementerian Kesehatan Republik Indonesia. Komite Penanggulangan Kanker Nasional., 1, 12-14, 24-26, 45. https://doi.org/10.1111/evo.12990

Khasanah.2013. Karsinoma mammae stadium IV dengan tanda-tanda dyspnoe dan paraplegi ekstrimitas inferior. Medula, 1, no 2(Oktober), 43-52. Retrieved from juke.kedokteran.unila.ac.id

Larasati, D. M.2016. Pengaruh terapi musik terhadap tingkat kecemasan sebelum bertanding pada atlet futsal, 1-11. https://doi.org/10.1111/j.14697610.2010.02280.x

Martini, M., Watiningsih, Pertama, A., \& Lisnayani, K.2018. Terapi distrkasi terhadap penurunan nyeri. Jurnal Kesehatan, 7 no 2(september), 353360.

https://doi.org/10.24252/kesehatan.v $7 \mathrm{i} 2.54$

Munawaroh, K.2018. Gambaran skala nyeri pada pasien panker kolorektal yang menjalani kemoterapi. Gaster | Jurnal Ilmu Kesehatan, 16(2), 160. https://doi.org/10.30787/gaster.v16i2 .291

Rahayuwati, L., Ibrahim, K., \& Komariah, M.2018. Pilihan pengobatan pasien kanker payudara masa kemoterapi: Studi kasus. Jurnal Keperawatan Indonesia, 20(2), 118. 
https://doi.org/10.7454/jki.v20i2.478

Ramli, M.2015. Update breast cancer management diagnostic and treatment. Majalah Kedokteran Andalas, 38(1), 40. Retrieved from http://jurnalmka.fk.unand.ac.id

Ricky, Rachmawaty, R., \& Syam, Y. 2018. Efektifitas progressive muscle relaxation terhadap kecemasan pada pasien kanker payudara yang menjalani

kemoterapi. Jurnal Terpadu Ilmu Kesehatan, 7, no 2(november), 101221.

Rilla, E. V., Ropii, H., \& Sriati, A. 2017. Terapi murrotal efektif menurunkan tingkat nyeri dibanding terapi musik pada pasien pascabedah. Jurnal Keperawatan Indonesia, 17(2), 7480.

https://doi.org/10.7454/jki.v17i2.444

Sitinjak, L., Rulino, L., \& Masliah, R. 2018. Manajemen nyeri pada pasien kanker payudara dengan menggunakan tehnik distraksi terapi musik, 4(2), 34-39. 